\title{
PERAN KEHARMONISAN KELUARGA DAN PENERIMAAN TEMAN SEBAYA TERHADAP KONSEP DIRI REMAJA SMP DI DENPASAR
}

\author{
A.A. Ayu Trisna Dewi dan I Made Rustika \\ Program Studi Psikologi, Fakultas Kedokteran, Universitas Udayana \\ trisna.dewi002@gmail.com
}

\begin{abstract}
Abstrak
Konsep diri merupakan aspek mental yang sangat penting pada kehidupan remaja karena mampu mempengaruhi perilaku remaja. Konsep diri bukan dibawa sejak lahir, namun dipengaruhi oleh stimulus lingkungan sejak usia dini. Kondisi keluarga merupakan salah satu stimulus lingkungan yang dapat mempengaruhi konsep diri. Dalam kehidupan di luar rumah, respon teman sebaya ketika berinteraksi juga sangat berperan terhadap konsep diri. Penelitian ini bertujuan untuk mengetahui peran keharmonisan keluarga dan penerimaan teman sebaya terhadap konsep diri remaja SMP di Denpasar.

Subjek dalam penelitian ini adalah 224 orang remaja SMP di Denpasar yang diwakili oleh SMPN 1 Denpasar. Instrumen dalam penelititan ini adalah skala konsep diri, keharmonisan keluarga dan skala penerimaan teman sebaya.

Dari hasil analisis regresi berganda menunjukan $\mathrm{R}=0,560(\mathrm{~F}=50,395 ; \mathrm{p}<0,05)$ dengan demikian dapat disebutkan bahwa keharmonisan keluarga dan penerimaan teman sebaya secara bersama-sama berperan terhadap konsep diri. Koefisien determinasi sebesar 0,313 menunjukkan bahwa sumbangan efektif dari keharmonisan keluarga dan penerimaan teman sebaya terhadap konsep diri sebesar $31,3 \%$. Nilai beta terstandarisasi pada keharmonisan keluarga dengan konsep diri sebesar $0,285(\mathrm{p}<0,05)$ sedangkan pada penerimaan teman sebaya dengan konsep diri sebesar $0,361(\mathrm{p}<0,05)$. Dengan demikian dapat disebutkan peran penerimaan teman sebaya lebih besar dibandingkan keharmonisan keluarga terhadap konsep diri.
\end{abstract}

Kata Kunci : konsep diri, keharmonisan keluarga, penerimaan teman sebaya, remaja SMP.

\begin{abstract}
The self-concept is a very important mental aspect in a early adolescent's life because it can influence their behavior. Self-concept is not innate, but rather influenced by environmental stimuli at an early age. Family condition is one of the environmental stimuli that can influence self-concept. In outside-the home life, the responses of peers while interacting also contribute significantly to the self-concept. This study aims to determine the roles of family harmony and peer acceptance to teenagers' self-concept of Junior High School adolescent in Denpasar.

Subjects in this study were 224 of Junior High School adolescent in Denpasar, represented by the State Junior High School 1 of Denpasar. Instruments in this study were self-concept scale, family harmony and scale of peer acceptance.

The results of multiple regression analysis shows that $\mathrm{R}=0.560(\mathrm{~F}=50.395, \mathrm{p}<0.05)$, it can be stated that the harmony of the family and peer acceptance jointly contribute to the self-concept. Determination coefficient of 0.313 indicates that the effective contribution of family harmony and peer acceptance to the self-concept amounted to $31.3 \%$. Standardized beta values on family harmony with the self-concept is $0.285(\mathrm{p}<0.05)$ whereas peer acceptance with the self-concept at $0.361(\mathrm{p}<0.05)$. Thus it can be stated the role of peer acceptance is greater than the harmony of the family for the self- concept.
\end{abstract}

Keywords: self-concept, family harmony, peer acceptance, junior high school adolescent 


\section{LATAR BELAKANG}

Masa remaja merupakan masa transisi dari masa anak-anak menuju masa dewasa yang berlangsung sejak usia 10 atau 11 tahun, atau bahkan lebih awal yang disebut dengan early puberty hingga usia dua puluhan awal yang disebut dengan remaja akhir. Selama periode ini, tidak hanya terjadi perubahan emosional dan sosial tetapi juga perubahan fisik pada individu (Papalia, Olds, \& Fieldmans, 2009). Periode ini juga merupakan periode yang mengandung risiko karena sebagian besar remaja mengalami permasalahan dalam menghadapi berbagai perubahan yang terjadi secara bersamaan dan membutuhkan bantuan dalam mengatasi bahaya saat menjalani masa ini.

Memasuki masa remaja berarti memasuki tahap storm and stress dalam perkembangan jiwa manusia, yaitu masa remaja yang penuh dengan masalah, tuntutan, dan tekanan dalam hidupnya. Pada masa ini, khususnya masa remaja awal, status remaja awal tidak hanya sulit ditentukan, tetapi juga membingungkan. Perlakuan orang tua terhadap remaja sering berganti-ganti. Orang tua ragu memberikan tanggungjawab dengan alasan remaja masih kanak-kanak. Tetapi saat remaja bertingkah kekanak-kanakan, remaja mendapat teguran sebagai orang dewasa, sehingga remaja bingung akan statusnya (Mappiare, 1982). Sikap, pikiran, pemahaman, penentuan pendapat, serta emosi pada masa remaja awal masih terus berkembang dan belum stabil (Papalia, dkk, 2009). Adanya permasalahan atau pergolakan emosi yang terjadi pada remaja awal muncul akibat banyaknya tuntutan dan harapan baru, baik dari dalam maupun dari luar diri individu. Permasalahan yang dialami remaja merupakan suatu hal yang harus dihadapi dan dipecahkan karena jika tidak diselesaikan akan menimbulkan kecemasan, ketegangan, dan konflik yang secara tidak langsung akan mempengaruhi kepribadiannya. Kenyataan yang sering dilihat, saat perkembangan remaja menuju kedewasaan, individu tidak selalu dapat menunjukkan siapa dirinya dan apa peranannya di dalam masyarakat.

Konsep diri merupakan salah satu bagian dari kepribadian. Konsep diri merupakan keseluruhan cara bagaimana individu melihat atau memahami dirinya sendiri. Konsep diri disusun dari semua persepsi terhadap "aku" dan "saya" dengan semua perasaan, nilai-nilai dan kepercayaan menyatu dengan semua bagian tersebut. Konsep diri terdiri dari bagaimana individu memandang dirinya sendiri yang biasa disebut dengan gambaran diri (Self Image), bagaimana individu menilai dirinya sendiri yang disebut dengan Self Evaluation, dan bagaimana individu menginginkan dirinya untuk menjadi seperti yang individu harapkan atau yang biasa disebut Ideal Self (Atwater, 1983). Menurut pandangan Rogers (dalam Feist \& Feist, 2010), konsep diri merefleksikan bagaimana individu memandang dirinya dalam hubungannya dengan peran-peran yang individu jalankan dalam kehidupan, peran-peran tersebut diperoleh dari banyaknya interaksi dengan orang lain. Konsep diri sangat berperan dalam perilaku individu karena seluruh sikap dan pandangan individu terhadap dirinya akan mempengaruhi individu tersebut dalam mempersepsikan setiap aspek pengalaman-pengalamannya. Individu memandang atau menilai dirinya sendiri dapat dilihat dari seluruh perilaku yang ditunjukkan. Apabila individu memandang dirinya sebagai seorang yang memiliki cukup kemampuan untuk melaksanakan tugas, maka individu itu akan menampakkan perilaku sukses dalam melaksanakan tugasnya. Sebaliknya apabila individu memandang dirinya sebagai seorang yang kurang memiliki kemampuan dalam melaksanakan tugas, maka individu itu akan menunjukkan ketidakmampuan dalam perilakunya.

Menurut Burns (dalam Hutagalung, 2007) ciri dari individu yang memiliki konsep diri negatif ialah sangat peka dan sulit menerima kritik dari orang lain, sulit berinteraksi dengan orang lain, sulit mengakui kesalahan, kurang mampu mengungkapkan perasaan dengan cara yang wajar, menunjukkan sikap mengasingkan diri, merasa tidak berdaya, tidak menyukai persaingan dan malu-malu. Individu dengan konsep diri negatif akan cenderung bersikap pesimistik terhadap kehidupan dan kesempatan yang dihadapinya. Individu tersebut tidak melihat tantangan sebagai kesempatan, namun lebih sebagai halangan, mudah menyerah sebelum menghadapi sesuatu dan ketika gagal akan cenderung menyalahkan diri sendiri atau menyalahkan orang lain. Individu yang memiliki konsep diri yang positif akan terlihat lebih optimis, penuh percaya diri dan selalu bersikap positif terhadap segala sesuatu, termasuk juga terhadap kegagalan yang dialaminya. Kegagalan bukan dipandang sebagai kematian, tapi sebagai penemuan dan pelajaran berharga untuk melangkah ke depan. Orang dengan konsep diri yang positif akan mampu menghargai dirinya dan melihat hal-hal positif yang dapat dilakukan demi keberhasilan di masa yang akan datang. Adanya perbedaan perkembangan konsep diri tersebut memunculkan sebuah pertanyaan pada peneliti mengapa ada individu yang memiliki konsep diri positif sedangkan yang lainnya memiliki konsep diri negatif.

Menurut Hurlock (1980) banyak faktor yang mempengaruhi konsep diri remaja, salah satunya ialah hubungan dalam keluarga dan juga teman sebaya. Salah satu ciri dari remaja awal adalah berusaha untuk mandiri namun masih sangat membutuhkan orangtua (Ahmadi \& Sholeh, 2005). Keluarga merupakan bagian terpenting dari kehidupan seorang anak karena di dalam keluarga, anak pertama kali belajar tentang segala hal, baik berinteraksi ataupun belajar norma-norma. Keluarga juga memiliki peranan penting dalam pembentukan konsep diri pada remaja. Kasih sayang, perhatian, kehangatan dan keutuhan keluarga sangat dibutuhkan remaja untuk membantu membentuk konsep diri yang ideal. Remaja dapat mempersepsikan dirinya melalui 
interaksi yang dilakukan, pertama kali adalah dengan lingkungan keluarga (Ahmadi \& Sholeh, 2005). Remaja yang dibesarkan dalam keluarga yang memiliki orangtua lengkap dengan suasana keluarga positif cenderung untuk mengarungi masa depan tanpa masalah serius. Dalam memasuki kehidupan rumah tangga yaitu sebagai orangtua, remaja cenderung memiliki pernikahan yang kuat dan menjalani hidup dengan sangat nyaman (Papalia, dkk, 2009).

Kenyataan yang ada, tidak semua orangtua mampu memberikan kasih sayang, perhatian, kehangatan dan keutuhan keluarga kepada anak-anaknya. Salah satu permasalahan dalam keluarga ialah adanya hubungan antara ayah dan ibu yang tidak harmonis lagi, orangtua tidak bisa lagi menjadi panutan bagi anak-anaknya. Keharmonisan dalam keluarga tersebut selanjutnya dapat berdampak pada perceraian, pisah ranjang, atau adanya keributan yang terus menerus terjadi dalam keluarga (Papalia, dkk, 2009). Hubungan ayah dan ibu yang tidak harmonis akan berdampak bagi perkembangan anak-anaknya. Remaja yang mengalami permasalahan, cenderung berasal dari keluarga yang tidak stabil dan menolak norma budaya. Hal tersebut didukung oleh penelitian yang dilakukan oleh Maria (2007) yang menunjukkan bahwa ada peran persepsi keharmonisan keluarga terhadap kecenderungan kenakalan remaja. Penelitian lainnya yang terkait adalah penelitian oleh Afiah dan Purnamasari (2007) yang menunjukkan bahwa ada hubungan negatif yang sangat signifikan antara keharmonisan keluarga dan sikap terhadap seks pranikah pada remaja. Dengan demikian dapat dikatakan bahwa keadaan hubungan ayah dan ibu yang tidak harmonis dapat berpengaruh terhadap persepsi diri remaja yang selanjutnya mempengaruhi perilaku yang remaja tunjukkan.

Pada penelitian yang dilakukan oleh Sukmanti (2005) menunjukkan bahwa ada hubungan positif antara keharmonisan keluarga dan konsep diri siswa kelas II di Sekolah Menengah Atas Negeri 1 Kejobong Purbalingga. Kondisi keluarga yang harmonis mampu menciptakan konsep diri yang positif pada individu karena individu mendapatkan kasih sayang, perhatian, dukungan dan kehangatan dari keluarganya. Dengan kata lain, lingkungan keluarga merupakan tempat pembentukan kepribadian anggotaanggotanya, sehingga kualitas lingkungan keluarga akan mampu mempengaruhi pembentukan konsep diri.

Selain keluarga, teman sebaya juga merupakan salah satu faktor yang mempengaruhi konsep diri. Meskipun remaja awal masih bergantung pada orang tuanya, namun intensitas ketergantungan tersebut telah berkurang dan remaja awal mulai mendekatkan diri pada teman-teman sebayanya. Sesuai dengan salah satu ciri dari remaja awal yaitu mulai mendekatkan diri dengan teman sebaya dan berusaha bebas dari ketergantungan orangtua (Monks, Knoers, \& Haditono, 2004). Teman sebaya berperan sangat penting pada diri remaja. Teman sebaya merupakan sumber status, persahabatan dan rasa saling memiliki yang penting di sekolah. Kelompok teman sebaya juga merupakan komunitas belajar peran-peran sosial dan standar yang berkaitan dengan kerja dan prestasi (Santrock, 2003). Teman sebaya memiliki peranan yang begitu penting sehingga para remaja berusaha melakukan berbagai cara agar bisa diterima oleh teman sebayanya. Penerimaan teman sebaya dapat dilihat dari persepsi mereka terhadap reaksi dari teman sebayanya (Durkin, 1995).

Salah satu tugas perkembangan remaja adalah memupuk kemampuan bersosialisasi dengan memperluas hubungan antar pribadi dan berinteraksi secara lebih dewasa dengan teman sebaya (Hurlock, 1980). Pentingnya pencapaian dari tugas perkembangan remaja adalah remaja akan merasa bahagia apabila aspirasi remaja terpenuhi, demikian pula dengan harapan masyarakat. Dalam mengembangkan kemampuan sosialnya, remaja cenderung bergabung dengan kelompok dan banyak berpartisipasi dalam aktivitas-aktivitas kelompok. Kemampuan remaja untuk dapat masuk dan bergabung serta beraktivitas bersama dalam kelompok sebayanya dapat dilihat dari sejauhmana remaja dapat menyesuaikan diri terhadap pendapat kelompok yang diikutinya. Kondisi ini akan membantu remaja untuk memperoleh gambaran tentang dirinya yang lebih baik karena ketika remaja memiliki kemampuan dalam menyesuaikan diri dan mampu beraktivitas serta diterima dengan baik dalam kelompok sebayanya membuat remaja memiliki persepsi akan gambaran diri yang positif. Sesuai dengan apa yang disampaikan oleh Mappiare (1982) bahwa dengan diterimanya remaja dalam kelompok teman sebayanya, maka akan membuat remaja merasa dirinya dihargai dan dihormati oleh teman-temannya, sehingga akan menimbulkan rasa senang, gembira, puas terhadap diri dan memberikan rasa percaya diri yang besar. Rasa percaya diri yang besar serta rasa puas terhadap diri merupakan cerminan dari konsep diri yang positif.

Penerimaan kelompok sebaya itu sendiri merupakan persepsi tentang diterima atau dipilihnya individu tersebut menjadi anggota dalam suatu kelompok tertentu (Hurlock, 1980). Seorang remaja yang diterima di sekolahnya baik karena faktor fisik yang baik, kemampuan intelektual maupun sikap yang ramah dan rendah hati, akan merasa bahagia dan memiliki konsep diri yang positif (Mappiare, 1982). Remaja yang tidak diterima di kelompok sebayanya di sekolah cenderung memiliki konsep diri yang negatif. Hal ini sesuai dengan apa yang disampaikan oleh Hurlock bahwa apabila remaja memandang dirinya diterima di dalam kelompok, maka selanjutnya mereka akan menyesuaikan perilaku dengan perilaku yang diharapkan kelompok sehingga hal tersebut akan berdampak pada perkembangan psikologis remaja seperti mereka akan merasa bahagia, optimis, dan terbentuk konsep diri yang positif. Sebaliknya, bila mereka memandang bahwa 
mereka tidak diterima oleh kelompoknya maka berbagai akibat negatif akan timbul. Mereka akan merasa kesepian, tidak aman, memiliki konsep diri yang negatif, kurang memiliki pengalaman belajar, sedih, kurang memiliki keterampilan sosial, dan melakukan penyesuaian sosial secara berlebihan (Hurlock, 1980). Pengabaian dan penolakan dari teman sebaya juga dapat mengakibatkan para remaja merasa kesepian dan timbul rasa permusuhan yang selanjutnya berhubungan dengan kesehatan mental individu dan masalah kriminal. Selain itu, penolakan dari teman sebaya dalam pertemanan dapat memunculkan perilaku-perilaku negatif yang merupakan cerminan dari konsep diri yang negatif (Santrock, 2003).

Berdasarkan pemaparan diatas maka peneliti ingin mengetahui peran keharmonisan keluarga dan penerimaan teman sebaya terhadap konsep diri pada remaja SMP di Denpasar. Penelitian ini diharapkan dapat memberikan manfaat dalam pengembangan kajian ilmu psikologi khususnya pada ilmu psikologi perkembangan, kepribadian, dan sosial terkait dengan keharmonisan keluarga, penerimaan teman sebaya dan konsep diri pada remaja SMP. Manfaat praktis dari penelitian ini adalah bagi remaja awal diharapkan penelitian ini dapat memberikan kesadaran pada remaja untuk mengembangkan persahabatan dengan sebayanya dimana dengan mengembangkan persahabatan maka remaja dapat mengembangkan rasa empati yang merupakan hal yang penting untuk memperoleh penerimaan dari teman sebayanya. Selain itu, diharapkan penelitian ini juga mampu membuat remaja memahami pentingnya arti keluarga, sehingga remaja mampu untuk lebih mendekatkan diri dengan orangtuanya. Bagi orangtua yaitu pentingnya membantu remaja dalam mengembangkan konsep diri yang positif dengan memberikan suasana keluarga yang hangat serta nyaman bagi remaja sehingga remaja dapat merasa bahwa dirinya aman berada di dalam keluarganya serta remaja juga merasa bahwa ia mendapat dukungan dan bantuan dari keluarga dalam melewati masa remaja yang merupakan masa pencarian identitas sehingga remaja mampu memperoleh identitasnya serta mengenali dirinya secara utuh dan membentuk konsep diri yang positif. Bagi sekolah yaitu informasi mengenai pentingnya penerimaan teman sebaya, sehingga diharapkan sekolah dapat membantu meminimalkan adanya diskriminasi di sekolah dengan mengawasi siswa-siswa di sekolah. Usaha meminimalkan tindakan diskriminasi dapat dilakukan dengan mengadakan kegiatan berkelompok yang lebih banyak bagi seluruh siswa baik dalam kegiatan kurikuler maupun ekstrakurikuler dibandingkan dengan kegiatan individual. Hal tersebut dapat meningkatkan adanya kekompakan serta mampu mengembangkan rasa empati, persahabatan, tolong menolong dan lainnya. Bagi masyarakat diharapkan penelitian ini dapat menyumbangkan informasi terkait faktor-faktor yang mampu menumbuhkan konsep diri yang positif bagi remaja.

\section{METODE PENELITIAN}

\section{Variabel dan definisi operasional}

Variabel bebas dalam penelitian ini adalah keharmonisan keluarga dan penerimaan teman sebaya sedangkan variabel terikat dalam penelitian ini ialah konsep diri. Adapun definisi operasional dari masing-masing variabel penelitian ialah sebagai berikut:

1. Konsep Diri adalah gambaran dan penilaian individu tentang keadaan diri secara keseluruhan, meliputi fisik dan psikologis saat sekarang dan keinginan dimasa mendatang. Konsep diri diukur dengan skala konsep diri yang disusun berdasarkan delapan aspek konsep diri dari Fitts, yaitu identitas diri (self identity), diri sebagai pelaku (behavioral self), diri sebagai penilai (judging self), diri fisik (physical self), diri etika moral (moral ethical self), diri personal (personal self), diri keluarga (family self), diri sosial (social self). Skor total item yang diperoleh menunjukkan konsep diri yang dimiliki subjek. Semakin tinggi skor yang diperoleh maka semakin positif konsep diri subjek penelitian.

2. Keharmonisan keluarga ialah suatu keadaan keluarga yang kukuh dan bahagia, yang ditandai oleh minimnya ketegangan, kekecewaan, mampu menjalankan hak dan kewajibannya masing-masing, terjalinnya kasih sayang, pengertian, komunikasi, dan kerjasama yang baik antar anggota keluarga. Keharmonisan keluarga diukur dengan skala keharmonisan keluarga yang disusun berdasarkan enam aspek keharmonisan keluarga dari Defrain dan Stinnett (dalam Lestari, 2012) yaitu memiliki komitmen, terdapat kesediaan untuk mengungkapkan apresiasi, terdapat waktu untuk berkumpul bersama, mengembangkan spiritualitas, menyelesaikan konflik dan menghadapi tekanan dan krisis dengan efektif, dan memiliki ritme. Skor total item yang diperoleh menunjukkan seberapa harmonis hubungan di dalam keluarga subjek. Semakin tinggi skor yang diperoleh maka semakin harmonis hubungan di dalam keluarga subjek penelitian.

3. Penerimaan teman sebaya merupakan cerminan perasaan senang dan pemberian cinta tanpa syarat dari seorang individu terhadap individu lainnya yang memiliki usia sama dalam melakukan suatu aktivitas kelompok dengan mematuhi nilainilai yang berlaku dan telah ditetapkan oleh kelompok. Penerimaan teman sebaya diukur dengan skala penerimaan teman sebaya yang disusun berdasarkan enam aspek penerimaan teman sebaya dari Parker yaitu validation and caring, companionshipand recreation, help and guidance, intimate exchange, conflict and betrayal, conflict resolution. Skor total item yang diperoleh menunjukkan seberapa tinggi penerimaan teman sebaya subjek. Semakin tinggi skor yang diperoleh maka semakin diterima subjek di dalam kelompoknya. 


\section{Responden}

Populasi yang digunakan dalam penelitian ini adalah remaja SMP di Denpasar. Subjek dalam penelitian ini adalah sebagian remaja SMP di Denpasar. Teknik pengambilan sampel dalam penelitian ini dengan menggunakan teknik random sampling yaitu multistage random sampling. Multistage random sampling (sampling acak bertingkat) merupakan metode pengambilan sampel yang dilakukan karena sampel dalam penelitian memiliki karakteristik berkluster dan berstrata (Purwanto, 2010). SMP di Denpasar memiliki karakteristik berkluster, sedangkan untuk pengambilan sampel di dalam SMP memiliki karakteristik berstrata yaitu dari kelas VII sampai dengan kelas IX. Jumlah responden dalam penelitian ini adalah 224 orang.

\section{Tempat penelitian}

Proses pengambilan sampel dilakukan di SMPN 1 Denpasar yang menjadi SMP terpilih setelah melakukan random. Penelitian dilaksanakan pada bulan Maret 2015.

\section{Alat ukur}

Alat ukur yang digunakan dalam penelitian ini adalah 3 (tiga) skala yaitu skala konsep diri, skala keharmonisan keluarga, dan skala penerimaan teman sebaya. Skala konsep diri dimodifikasi dari skala Putra (2014) dengan menggunakan dimensi Fitts , skala keharmonisan keluarga disusun berdasarkan enam aspek keharmonisan keluarga dari Defrain dan Stinnett (dalam Lestari, 2012), dan skala penerimaan teman sebaya disusun berdasarkan enam aspek penerimaan teman sebaya dari Parker dan Asher (1993) dengan menggunakan model skala likert. Skala konsep diri terdiri dari 37 item pernyataan, skala keharmonisan keluarga terdiri dari 31 item pernyataan, dan skala penerimaan teman sebaya terdiri dari 30 item pernyataan. Skala konsep diri, keharmonisan keluarga dan penerimaan teman sebaya disusun dalam bentuk pernyataan favorable dan unfavorable yang diberi skor mulai dari 1 sampai 4. Pada skala konsep diri, kerharmonisan keluarga, dan penerimaan teman sebaya terdapat 4 respon jawaban, yaitu sangat setuju (SS), setuju (S), tidak setuju (TS), dan sangat tidak setuju (STS). Pada pernyataan dalam aitem favorable jawaban sangat setuju (SS) diberi skor 4, setuju (S) diberi skor 3, tidak setuju (TS) diberi skor 2, dan sangat tidak setuju (STS) diberi skor 1. Sedangkan dalam pernyataan dalam aitem unfavorable jawaban sangat setuju (SS) diberi skor 1, setuju (S) diberi skor 2, tidak setuju (TS) diberi skor 3, dan sangat tidak setuju (STS) diberi skor 4.

Pada pengujian validitas skala konsep diri koefisien korelasi item total bergerak dari 0,282 sampai dengan 0,631. Hasil reliabilitas skala konsep diri dengan menggunakan
Cronbach Alpha $(\alpha)$ adalah sebesar 0.894. Alpha $(\alpha)$ sebesar 0,894 menunujukkan bahwa skala ini mampu mencerminkan $89,4 \%$ variasi skor subjek adalah skor murni. Hasil tersebut menggambarkan skala konsep diri dapat digunakan untuk mengukur konsep diri.

Pada pengujian validitas skala keharmonisan keluarga koefisien korelasi item total bergerak dari 0,264 sampai dengan 0,542. Hasil reliabilitas skala keharmonisan keluarga dengan menggunakan Cronbach Alpha $(\alpha)$ adalah sebesar 0,882. Alpha $(\alpha)$ sebesar 0.882 menunujukkan bahwa skala ini mampu mencerminkan $88,2 \%$ variasi skor subjek adalah skor murni. Hasil tersebut menggambarkan skala keharmonisan keluarga dapat digunakan untuk mengukur keharmonisan keluarga.

Pada pengujian validitas skala penerimaan teman sebaya koefisien korelasi item total bergerak dari 0,340 sampai dengan 0,647. Hasil reliabilitas skala penerimaan teman sebaya dengan menggunakan Cronbach Alpha $(\alpha)$ adalah sebesar 0,914. Alpha $(\alpha)$ sebesar 0.914 menunujukkan bahwa skala ini mampu mencerminkan $91,4 \%$ variasi skor subjek adalah skor murni. Hasil tersebut menggambarkan skala penerimaan teman sebaya dapat digunakan untuk mengukur penerimaan teman sebaya..

\section{Teknik analisis data}

Teknik analisis yang digunakan untuk dapat menguji hipotesis mayor dan minor dalam penelitian ini adalah analisis regresi berganda. Analisis ini digunakan untuk menguji hipotesis peran antara dua atau lebih variabel bebas dengan satu variabel tergantung (Yudiatmaja, 2013). Analisis dilakukan dengan bantuan perangkat lunak SPSS versi 15.00. Sebelum melakukan analisis dengan teknik regresi berganda, peneliti melakukan uji normalitas, multikolinieritas, dan linieritas terlebih dahulu. Uji normalitas sebaran data penelitian akan menggunakan teknik Kolmogorov-Smirnov Goodnessof Fit Test, uji multikolinearitas dalam penelitian ini dapat dilihat dari nilai tolerance dan nilai VIF (Variance Inflation Factor) dari model regresi, dan uji normalitas dengan menggunakan teknik Compare Means.

\section{HASIL PENELITIAN}

\section{Karakteristik Subjek}

Uji coba alat ukur dalam penelitian ini dilakukan terhadap Berdasarkan hasil data karakteristik subjek penelitian, diketahui bahwa subjek penelitian berjumlah 224 orang dengan laki-laki berjumlah 98 orang dan perempuan berjumlah 126 orang, rentang usia dari 12 tahun sampai 15 tahun, yang tersebar dari kelas VII sampai kelas IX.

\section{Deskripsi Data Peneleitian}




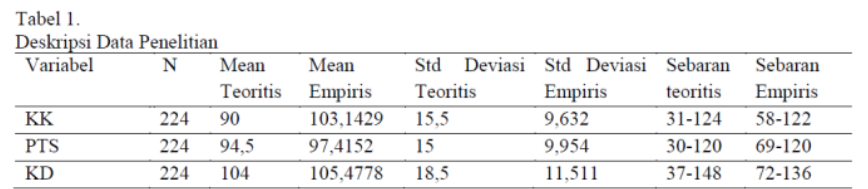

Perbedaan mean empiris dan mean teoritis pada variabel keharmonisan keluarga adalah 13,14. mean empiris lebih tinggi dari mean teoritis, menunjukkan bahwa terdapat perbedaan antara mean empiris dan mean teoritis pada keharmonisan keluarga. Rentang skor subjek penelitian antara 58 sampai dengan 122, yang berdasarkan penyebaran frekuensi $92,41 \%$ subjek berada diatas mean teoritis.

Perbedaan mean empiris dan mean teoritis pada variabel penerimaan teman sebaya adalah 2,92. mean empiris lebih tinggi dari mean teoritis, menunjukkan bahwa terdapat perbedaan antara mean empiris dan mean teoritis pada penerimaan teman sebaya. Rentang skor subjek penelitian antara 69 sampai dengan 120, yang berdasarkan penyebaran frekuensi $60,268 \%$ subjek berada diatas mean teoritis.

Perbedaan mean empiris dan mean teoritis pada variabel konsep diri adalah 1,48. mean empiris lebih tinggi dari mean teoritis, menunjukkan bahwa terdapat perbedaan antara mean empiris dan mean teoritis pada konsep diri. Rentang skor subjek penelitian antara 72 sampai dengan 136, yang berdasarkan penyebaran frekuensi 50,893\% subjek berada diatas mean teoritis.

\section{Uji Asumsi}

\begin{tabular}{lll}
$\begin{array}{l}\text { Tabel 2. } \\
\text { Uji Normalitas Variabel Penelitian }\end{array}$ & & \\
\cline { 2 - 2 } Variabel & Kolmogorof-Smirnov (K-S) Z & Asymp. Sig. (2 tailed) \\
\hline Keharmonisan Keluarga & 0.944 & 0.335 \\
\hline Penerimaan Teman Sebaya & 0.566 & 0.906 \\
\hline Konsep Diri & 1.199 & 0.113 \\
\hline
\end{tabular}

Berdasarkan data pada tabel 2, diketahui bahwa variabel keharmonisan keluarga memiliki nilai Kolmogorf Smirnof sebesar 0,944 dengan signifikansi sebesar 0,335 ( $p>0.05$ ). Hal ini menunjukkan bahwa keharmonisan keluarga memiliki distribusi normal. Data dari penerimaan teman sebaya memiliki nilai Kolmogorf Smirnof sebesar 0,566 dengan signifikansi sebesar 0,906 (p>0.05). Hal ini menunjukkan bahwa penerimaan teman sebaya memiliki distribusi normal. Data dari konsep diri memiliki nilai Kolmogorf Smirnof sebesar 1,199 dengan signifikansi sebesar 0,113 ( $p>0.05$ ). Hal ini menunjukkan bahwa konsep diri memiliki distribusi normal.

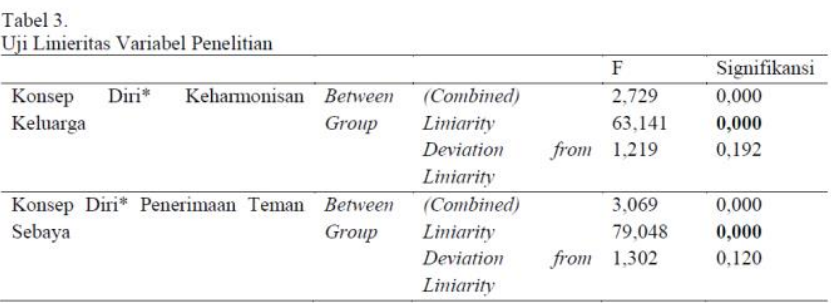

Hubungan dua variabel dikatakan linier apabila signifikansi Linierity lebih kecil dari 0.05. Berdasarkan tabel 3 , nilai signifikansi dari variabel konsep diri dengan variabel keharmonisan keluarga adalah 0,000 $(<0.05)$ dan variabel konsep diri dengan penerimaan teman sebaya adalah 0,000 $(<0,05)$. Maka dapat dikatakan bahwa terdapat hubungan linier antara konsep diri dengan keharmonisan keluarga serta konsep diri dengan penerimaan teman sebaya.

\begin{tabular}{lclll}
$\begin{array}{l}\text { Tabel } 4 . \\
\text { Uji Multikolinieritas Variabel Penelitian }\end{array}$ & & \\
\cline { 1 - 3 } Variabel & Signifikansi & \multicolumn{2}{l}{ Collinierity Statistics } & Keterangan \\
\cline { 2 - 4 } & & Tolerance & VIF & \\
\hline Keharmonisan Keluarga & 0,000 & 0,756 & 1,323 & $\begin{array}{l}\text { Tidak ad } \\
\text { multikolinieritas ada }\end{array}$ \\
\hline Penerimaan Teman Sebaya & 0,000 & 0,756 & 1,323 & $\begin{array}{l}\text { Tidak ada } \\
\text { multikolinieritas }\end{array}$ \\
\hline
\end{tabular}

Berdasarkan paparan hasil uji multikolinieritas diatas, terlihat bahwa nilai tolerance pada kedua variabel bebas yaitu sebesar 0,756 lebih besar dari 0,1, sedangkan nilai VIF sebesar 1,323 yang lebih kecil dari 10. Dari hasil tersebut, dapat disimpulkan bahwa tidak terjadi multikolinieritas atau tidak terdapat hubungan yang signifikan antara kedua variabel bebas pada penelitian ini.

Berdasarkan hasil uji normalitas, linieritas dan juga multikolinieritas yang telah peneliti lakukan, maka dapat disimpulkan bahwa data penelitian ini berdistribusi normal, berhubungan linier dan tidak ada gejala multikolinieritas, sehingga dapat dilanjutkan dengan melakukan uji regresi berganda.

\section{Uji Hipotesis}

Pada penelitian ini akan dilakukan uji hipotesis mayor dan juga uji hipotesis minor dengan menggunakan uji regresi berganda.

\section{Uji Regresi Berganda}

$$
\text { Tabel } 5 \text {. }
$$$$
\text { Hasil Uji Regresi Variabel Penelitia }
$$$$
\begin{array}{llll}
\multicolumn{1}{l}{\text { Hasil }} & R \text { Square } & \text { Adjusted } R \text { Square } & \text { Std. Error of the Estimate } \\
\hline 0,560 & 0,313 & 0,307 & 9,58245
\end{array}
$$

Hasil analisis regresi berganda menunjukkan koefisien regresi sebesar 0,560 dan koefisien determinasinya 0,313 sehingga dapat disebutkan sumbangan efektif kedua variabel bebas yaitu keharmonisan keluarga dan penerimaan teman sebaya terhadap variabel tergantung yaitu konsep diri sebesar $31,3 \%$ sedangkan sisanya sebesar $68,7 \%$ ditentukan oleh faktor lain yang tidak diteliti seperti usia kematangan, penampilan diri, kepatutan seks, nama dan julukan, kreatifitas 
dan cita-cita sesuai dengan yang disampaikan oleh Hurlock (1980).

\begin{tabular}{llllll}
\multicolumn{2}{l}{ Tabel 6. } \\
Hasil Uji Regresi Berganda Signifikansi Nilai $\mathrm{F}$ \\
\multicolumn{7}{l}{} & Sum of Squares & Df & Means Square & $F$ & Sig. \\
\hline Regression & 9254,917 & 2 & 4627,459 & 50,395 & 0,000 \\
\hline Residual & 20292,971 & 221 & 91,823 & & \\
\hline Total & 29547,888 & 223 & & & \\
\hline
\end{tabular}

Pada tabel 6 menunjukkan nilai $\mathrm{F}$ sebesar 50,395 dengan signifikansi sebesar 0,000, sehingga keharmonisan keluarga dan penerimaan teman sebaya dapat digunakan untuk memprediksi konsep diri karena memiliki signifikansi dibawah 0,05. Maka dapat dikatakan bahwa keharmonisan keluarga dan penerimaan teman sebaya bersama-sama berperan terhadap konsep diri. Dengan demikian hipotesis mayor dalam penelitian ini diterima.

\begin{tabular}{|c|c|c|c|c|c|c|}
\hline \multirow[b]{2}{*}{ Model } & & \multicolumn{2}{|c|}{$\begin{array}{l}\text { Unstandardized } \\
\text { Coefficients }\end{array}$} & \multirow{2}{*}{$\begin{array}{l}\text { Standardized } \\
\text { Coefficients } \\
\text { Beta }\end{array}$} & \multirow[b]{2}{*}{$t$} & \multirow[b]{2}{*}{ Sig. } \\
\hline & & $B$ & Std. Error & & & \\
\hline \multirow[t]{4}{*}{1} & (Constant) & 29,678 & 7,549 & & 3,876 & 0,000 \\
\hline & Keharmonisan & 0,341 & 0,077 & 0,285 & 4,448 & 0,000 \\
\hline & Keluarga & & & & & \\
\hline & $\begin{array}{l}\text { Penerimaan } \\
\text { Teman Sebaya }\end{array}$ & 0,417 & 0,074 & 0,361 & 5,627 & 0,000 \\
\hline
\end{tabular}

Nilai koefisien beta terstandarisasi keharmonisan keluarga sebesar 0,285 dengan nilai t sebesar 4,448 dan nilai signifikansi sebesar 0,000 lebih kecil dari 0,05. Hal tersebut menunujukkan bahwa keharmonisan keluarga memiliki peran yang signifikan terhadap konsep diri, sedangkan nilai koefisien beta terstandarisasi penerimaan teman sebaya sebesar 0,361 dengan nilai $t$ sebesar 5,627 dan nilai signifikansi sebesar 0,000 lebih kecil dari 0,05. Hal tersebut menunujukkan bahwa penerimaan teman sebaya memiliki peran yang signifikan terhadap konsep diri. Berdasarkan nilai koefisien beta terstandarisasi dua variabel bebas tersebut, terlihat bahwa penerimaan teman sebaya lebih berperan terhadap konsep diri dibandingkan dengan keharmonisan keluarga. Dengan demikian dapat disebutkan hipotesis minor dalam penelitian ini diterima.

Hasil uji hipotesis mayor dan hipotesis minor dalam penelitian ini dirangkum pada tabel 8 .

Tabel 8.

Hasil Uji Hipotesis Mayor dan Hipotesis Minor Penelitian

No Hipotesis Hasil

1 Hipotesis Mayor: Diterima

Keharmonisan Keluarga dan Penerimaan Teman Sebaya Berperan

Terhadap Konsep Diri Pada Remaja SMP di Denpasar

2 Hipotesis Minor:

Keharmonisan Keluarga Berperan Terhadap Konsep Diri Pada Remaja Diterima

SMP di Denpasar

Penerimaan Teman Sebaya Berperan Terhadap Konsep Diri Pada Diterima Remaja SMP di Denpasar

\section{PEMBAHASAN DAN KESIMPULAN}

Berdasarkan hasil penelitian yang telah dilakukan dan dianalisis dengan menggunakan teknik analisa regresi berganda, dapat diketahui bahwa pengujian hipotesis mayor adanya peran yang signifikan antara keharmonisan keluarga dan penerimaan teman sebaya terhadap konsep diri remaja awal dapat diterima. Hal tersebut dapat dilihat dari nilai koefisien regresi sebesar 0,560 dan koefisien determinasi sebesar 0,313 yang berarti bahwa keharmonisan keluarga dan penerimaan teman sebaya memiliki peran sebesar $31,3 \%$ terhadap konsep diri remaja awal dan sisanya sebesar $68,7 \%$ ditentukan oleh faktor lain yang tidak diteliti seperti usia kematangan, penampilan diri, kepatutan seks, nama dan julukan, kreatifitas dan cita-cita sesuai dengan yang disampaikan oleh Hurlock (1980). Koefisien beta terstandarisasi penerimaan teman sebaya adalah 0,361 sedangkan koefisien beta terstandarisasi keharmonisan keluarga adalah 0,285. Maka dapat dikatakan bahwa penerimaan teman sebaya lebih berperan terhadap konsep diri dibandingkan dengan keharmonisan keluarga. Perbedaan besarnya peran tersebut disebabkan karena pada masa remaja awal, individu mulai berusaha untuk tidak bergantung kepada orangtuanya, mereka mencoba untuk lebih mandiri, meskipun sebenarnya mereka masih membutuhkan orangtua mereka (Ahmadi \& Sholeh, 2005). Adanya keinginan untuk lebih mandiri membuat remaja lebih cenderung mengikuti temanteman sebayanya. Remaja cenderung lebih mempercayai teman-temannya dibandingkan dengan orangtuanya. Teman sebaya pada masa remaja ini mampu memberikan kebanggaan kepada remaja tersebut. Ketika remaja merasa dirinya lebih mampu di dalam kelompoknya, maka rasa bangga pada diri remaja juga akan berkembang yang akan mempengaruhi persepsi remaja terhadap dirinya. Remaja juga menganggap norma-norma yang ada di dalam kelompok teman sebayanya merupakan hal yang penting untuk ditaati walaupun tidak sesuai dengan norma-norma yang ditanamkan oleh orangtuanya.

Teman sebaya berperan sangat penting pada diri remaja. Teman sebaya merupakan sumber status, persahabatan dan rasa saling memiliki yang penting di sekolah. Kelompok teman sebaya juga merupakan komunitas belajar peran-peran sosial dan standar yang berkaitan dengan kerja dan prestasi (Santrock, 2003). Teman sebaya memiliki peranan yang begitu penting sehingga remaja berusaha melakukan berbagai cara agar bisa diterima oleh teman sebayanya. Diterima atau tidaknya remaja dalam lingkungan teman sebayanya dapat mempengaruhi bagaimana remaja mempersepsikan dirinya. Remaja cenderung akan mengikuti teman sebayanya walaupun hal tersebut merupakan perbuatan yang buruk. Hal itu dilakukan demi untuk diterima oleh kelompok. Remaja yang memiliki banyak teman dan merasa dirinya diterima di dalam kelompok sebaya cenderung mempersepsikan diri positif sehingga akan menunjukkan perilaku positif di lingkungan seperti rasa percaya diri yang tinggi dan mampu bersosialisasi dengan baik dalam lingkungan sosialnya yang merupakan cerminan dari konsep diri yang positif. Teman sebaya yang memberikan dukungan, perhatian dan menunjukkan kepedulian terhadap remaja ketika mengalami permasalahan 
akan mampu membuat remaja mempersepsikan bahwa keberadaan mereka dihargai dan diterima oleh temantemannya. Hal ini sesuai dengan pendapat yang dikemukakan oleh Hurlock (1980) yang menyatakan bahwa penerimaan dari teman sebaya akan menimbulkan perasaan senang dan aman, konsep diri yang positif, kesempatan mengembangkan perilaku yang dapat diterima, kebebasan mengalihkan perhatian ke dunia luar maupun penyesuaian sosial yang baik.

Dengan adanya hubungan yang harmonis di dalam keluarga akan mampu membantu anak untuk mengembangkan aspekaspek mental yang ada di dalam dirinya seperti salah satunya adalah konsep diri (Lestari, 2012). Konsep diri sangat penting bagi individu karena konsep diri akan mampu mempengaruhi bagaimana individu berperilaku di dalam masyarakat (Rogers dalam Burns 1993). Ketika konsep diri yang berkembang adalah konsep diri yang negatif, maka individu akan cenderung menunjukkan perilaku yang negatif juga. Pada penelitian yang dilakukan oleh Sukmanti (2005) menunjukkan bahwa ada hubungan positif antara keharmonisan keluarga dan konsep diri siswa kelas II di Sekolah Menengah Atas Negeri 1 Kejobong Purbalingga. Kondisi keluarga yang harmonis mampu menciptakan konsep diri yang positif pada individu karena individu mendapatkan kasih sayang, perhatian, dukungan dan kehangatan dari keluarganya. Dengan kata lain, lingkungan keluarga merupakan tempat pembentukan kepribadian anggota-anggotanya, sehingga kualitas lingkungan keluarga akan mampu mempengaruhi pembentukan konsep diri.

Hasil kategorisasi data konsep diri menunjukkan bahwa dua orang atau sekitar $0,893 \%$ subjek memiliki konsep diri sangat rendah, 29 orang atau sekitar 12,95\% subjek memiliki konsep diri rendah, sebanyak 136 orang atau sekitar $60,714 \%$ subjek memiliki konsep diri sedang, sedangkan 55 orang atau sekitar $24,55 \%$ subjek memiliki konsep diri tinggi dan dua orang atau sekitar $0,893 \%$ subjek memiliki konsep diri sangat tinggi. Hal ini menjelaskan bahwa mayoritas remaja SMP di Denpasar memiliki konsep diri yang sedang. Konsep diri sedang menunjukkan bahwa remaja SMP di Denpasar cukup mampu memahami dirinya secara keseluruhan baik secara fisik maupun mental dan mereka mampu menerima dirinya sebagaimana adanya.

Hasil kategorisasi data penerimaan teman sebaya menunjukkan bahwa tiga orang atau sekitar 1,34\% subjek memiliki penerimaan teman sebaya sangat rendah, 33 orang atau sekitar $14,73 \%$ subjek memiliki penerimaan teman sebaya rendah, sebanyak 123 orang atau sekitar 54,91\% subjek memiliki penerimaan teman sebaya sedang, sedangkan 59 orang atau sekitar $26,34 \%$ subjek memiliki penerimaan teman sebaya tinggi dan enam orang atau sekitar $2,68 \%$ subjek memiliki penerimaan teman sebaya sangat tinggi. Hal ini menjelaskan bahwa mayoritas remaja SMP di Denpasar memiliki penerimaan teman sebaya yang sedang. Penerimaan teman sebaya sedang menunjukkan bahwa remaja SMP di Denpasar mempersepsikan diri mereka cukup mampu diterima dengan baik oleh teman sebayanya.

Hasil kategorisasi data keharmonisan keluarga menunjukkan bahwa satu orang atau sekitar $0.4464 \%$ subjek memiliki keharmonisan keluarga sangat rendah, tiga orang atau sekitar $0.3393 \%$ subjek memiliki keharmonisan keluarga rendah, sebanyak 52 orang atau sekitar 23,214\% subjek memiliki keharmonisan keluarga sedang, sedangkan 139 orang atau sekitar $62,05 \%$ subjek memiliki keharmonisan keluarga tinggi dan 29 orang atau sekitar $12,95 \%$ subjek memiliki keharmonisan keluarga sangat tinggi. Hal ini menjelaskan bahwa mayoritas remaja SMP di Denpasar memiliki keharmonisan keluarga yang tinggi. Keharmonisan keluarga yang tinggi menunjukkan bahwa remaja SMP di Denpasar memiliki hubungan yang harmonis dalam keluarganya. Dengan adanya hubungan yang harmonis di dalam keluarga, maka remaja dapat memperoleh kasih sayang dan perhatian yang cukup dari orangtuanya, serta konflik di dalam keluarga dapat diminimalkan dan diselesaikan dengan efektif sehingga hal tersebut mampu membantu remaja dalam mengembangkan konsep dirinya ke arah yang positif.

Kemampuan remaja dalam memahami diri secara keseluruhan (konsep diri) tergolong menengah disebabkan karena penerimaan teman sebaya yang juga sedang. Hurlock (1980) menyatakan bahwa penerimaan dari teman sebaya akan menimbulkanperasaan senang dan aman, konsep diri yang positif, kesempatanmengembangkan perilaku yang dapat diterima, kebebasan mengalihkan perhatianke dunia luar maupun penyesuaian sosial yang baik. Apabila teman-teman remaja kurang mampu menerima remaja, maka remaja akan menganggap dirinya kurang berharga dan mengembangkan konsep diri yang kurang positif.

Penerimaan teman sebaya yang tergolong sedang pada penelitian ini juga disebabkan oleh adanya perbedaan kemampuan intelektual pada remaja yang berada dalam satu kelas. Hal tersebut membuat remaja lebih memilih untuk berteman dengan teman yang memiliki kemampuan intelektual yang baik dibandingkan dengan teman yang kemampuan intelektualnya kurang.Adanya perbedaan kemampuan intelektual tersebut membuat beberapa remaja menganggap bahwa teman-temannya tidak mau menerimanya. Hal tersebut terlihat pada nilai dari salah satu item skala penerimaan teman sebaya yaitu nomer 12 yang berbunyi "ketika saya tidak memahami suatu materi, tidak ada teman yang mau memberi penjelasan", sekitar 39 subjek menyatakan tidak setuju terhadap item tersebut. Selain karena perbedaan kemampuan intelektual, penerimaan teman sebaya ini juga dipengaruhi oleh kemampuan individu untuk mengendalikan emosi ( Mappiare, 1982). 40 subjek penelitian menyatakan bahwa dirinya kurang mampu untuk mengendalikan diri dengan baik pada item konsep diri nomer 28.Sesuai dengan 
penelitian yang dilakukan oleh Nisfiannoor dan Kartika (2004) menunjukkan adanya hubungan signifikan antara regulasi emosi dengan penerimaan kelompok teman sebaya pada remaja, sehingga apabila remaja mampu meregulasikan emosinya, maka remaja cenderung diterima dengan baik oleh peer groupnya.

Keharmonisan keluarga dalam penelitian ini tergolong tinggi karena mayoritas subjek dalam penelitian memiliki keluarga yang mampu memberikan apa yang dibutuhkan subjek, baik berupa materi maupun kebutuhan psikologis. Salah satu aspek dari keharmonisan keluarga adalah memiliki waktu bersama (Stinnet \& Defrain dalam Lestari, 2012) dan yang mempengaruhi keharmonisan keluarga adalah ekonomi keluarga (Gunarsa \& Gunarsa, 1999). Mayoritas dari subjek penelitian menyatakan bahwa keluarganya mau menyediakan waktu bersama ditengahtengah kesibukannya. Subjek penelitian juga memperoleh fasilitas pendidikan yang memadai dan hal tersebut menunjukkan bahwa subjek penelitian memiliki keluarga dengan perekonomian yang cukup.

Dari pemaparan semua data dan analisis diatas, maka tujuan dari penelitian ini telah mampu terpenuhi yaitu untuk mengetahui peran antara keharmonisan keluarga dan penerimaan teman sebaya terhadap konsep diri remaja SMP, serta mengetahui peran masing-masing variabel bebas yaitu keharmonisan keluarga terhadap konsep diri remaja awal dan peran penerimaan teman sebaya terhadap konsep diri remaja SMP.

Berdasarkan penelitian yang telah dilakukan dan hasil analisis data dapat ditarik kesimpulan yaitu Keharmonisan keluarga dan penerimaan teman sebaya secara bersama-sama berperan terhadap konsep diri remaja SMP di Denpasar dengan nilai koefisien determinasi sebesar 0,313. Keharmonisan keluarga memiliki peran terhadap konsep diri remaja SMP di Denpasar dengan nilai beta terstandarisasi sebesar 0,285. Penerimaan teman sebaya memiliki peran terhadap konsep diri remaja SMP di Denpasar dengan nilai beta terstandarisasi sebesar 0,361. Konsep diri remaja SMP di Denpasar tergolong menengah, karena berdasarkan mean empiris yang lebih besar dari mean teoritis diperoleh kategorisasi 60,714\% subjek memiliki konsep diri menengah. Keharmonisan keluarga pada remaja SMP di Denpasar tergolong tinggi, karena berdasarkan mean empiris yang lebih besar dari mean teoritis diperoleh kategorisasi $62,05 \%$ subjek memiliki keharmonisan keluarga yang tinggi. Penerimaan teman sebaya pada remaja SMP di Denpasar tergolong sedang, karena berdasarkan mean empiris yang lebih besar dari mean teoritis diperoleh kategorisasi 54,91\% subjek memiliki penerimaan teman sebaya yang sedang.

Berdasarkan kesimpulan tersebut, peneliti dapat memberikan saran bagi orangtua bahwa penting untuk menjaga hubungan yang harmonis di dalam keluarga, dengan memberikan dukungan, kasih sayang serta perhatian akan mampu mengembangkan konsep diri pada anak khususnya remaja. Bagi remaja awal yaitu belajar untuk lebih memahami diri sendiri dan mulai untuk mengembangkan persahabatan dengan teman sebaya merupakan hal yang penting agar dapat diterima dalam pertemanan, dan hal ini selanjutnya akan membantu berkembangnya konsep diri. Remaja juga diharapkan untuk lebih belajar dalam mengendalikan emosi yang merupakan salah satu faktor untuk diterima dalam lingkungan sosial teman sebaya. Selain itu, dalam memilih teman juga harus memperhatikan apakah yang menjadi minat dalam kelompok tersebut merupakan hal yang positif atau negatif. Minat yang positif dapat membantu individu dalam mengembangkan hal-hal positif yang ada di dalam dirinya. Bagi Sekolah yaitu menerapkan metode belajar dengan berkelompok akan mampu menumbuhkan rasa saling peduli pada remaja serta dengan menyediakan media untuk mengembangkan kerjasama dalam kelompok seperti ekstrakurikuler pramuka dan sebagainya. Bagi peneliti selanjutnya diharapkan dapat melakukan penelitian serupa tidak hanya kepada remaja awal saja, melainkan juga kepada remaja tengah dan juga remaja akhir untuk mengetahui konsep diri mereka ditinjau dari keharmonisan keluarga dan penerimaan teman sebaya serta dapat melakukan penelitian serupa pada daerah di Bali selain Denpasar.

\section{DAFTAR PUSTAKA}

Afiah, F. N. \& Purnamasari, S. E. (2007). Hubungan Antara Keharmonisan Keluarga Dengan Sikap Terhadap Seks Pranikah Pada Remaja. Jurnal Psikologi Perkembangan.

Ahmadi, A. \& Sholeh, M. (2005). Psikologi Perkembangan. Jakarta: PT Rineka Cipta

Atwater, E. (1983). Psychology of Adjustment (Second Edition). United States ofAmerica: Prentice Hall.

Burns, R.B. (1993). Konsep Diri Teori Pengukuran, Perkembangan dan Perilaku. Jakarta: Arcan. Editor: Eddy.

Durkin, K. (1995). Developmental Social Psychology from Infancy to Old Age. New York: Blackwell Publisher

Feist, J. \& Feist, G.J. (2010). Teori Kepribadian (7th ed., Vol. 1\& 2). Jakarta: Salemba Humanika.

Gunarsa, S.D.Y.\& Gunarsa, S.D. (1999). Psikologi Praktis: Anak. Remaja, dan Keluarga. Jakarta: PT BPK Gunung Mulia

Hurlock, E. B. (1980). Psikologi Perkembangan Suatu Pendekatan Sepanjang Rentang Kehidupan (5th ed.). Jakarta: Erlangga. 
Hutagalung, I. (2007). Pengembangan Kepribadian: Tinjauan Praktis Menuju Pribadi yang Positif. Jakarta: PT. INDEKS

Lestari, S. (2012). PSIKOLOGI KELUARGA Penanaman Nilai dan Penanganan Konflik dalam Keluarga. Jakarta: Kencana Prenada Media Group.

Mappiare, A. (1982). Psikologi Remaja. Surabaya: Usaha Nasional

Maria, U. (2007). Peran Persepsi Keharmonisan Keluarga Dan Konsep Diri Terhadap Kecenderungan Kenakalan Remaja. Thesis(tidak diterbitkan). Program Studi Psikologi Universitas Gadjah Mada, Jogyakarta

Monks, F.J., Knoers, A.M.P. \& Haditono, S.R. (2004). Psikologi Perkembangan Pengantar dalam Berbagai Bagiannya. Yogyakarta: Gadjah Mada University Press.

Nisfiannoor, M., \& Kartika, Y. (2004). Hubungan Antara Regulasi Emosi Dan Penerimaan Kelompok Teman Sebaya Pada Remaja. Jurnal Psikologi. 2 (2)

Papalia, D.E., Olds, S.W. \& Feldman, R.D. (2009). Human Development Perkembangan Manusia (10th ed.). Jakarta: Salemba Humanika.

Parker, J.G. \& Asher, S.R. (1993). Friendship and Friendship Quality in Middle Childhood: Links With Peer Group Acceptance and Feelings of Loneliness and Social Dissatisfaction. Developmental Psychology, 29 (4), 611-621

Purwanto. (2010). Metodologi Penelitian Kuantitatif untuk Psikologi dan Pendidikan. Yogyakarta: Pustaka Pelajar.

Putra, I.D.G.U. (2014). Hubungan Antara Perilaku Menolong Dengan Konsep Diri Pada Remaja Akhir Yang Menjadi Anggota Tim Bantuan Medis Janar Duta Fakultas Kedokteran Universitas Udayana. Skripsi (Tidak Dipublikasikan). Program Studi Psikologi Fakultas Kedokteran Universitas Udayana, Bali

Santrock, J. W. (2003). ADOLESCENCE Perkembangan Remaja. Jakarta: Erlangga.

Sukmanti, P. (2005).Hubungan antara KeharmonisanKeluarga dengan Konsep Diri Siswa kelas II SMA Negeri 1 KejobongTahun Pelajaran 2004/2005. Skripsi (Tidak Dipublikasikan). Fakultas Ilmu Pendidikan Universitas Negeri Semarang, Semarang.

Yudiatmaja, F. (2013). Analisis REGRESI Dengan Menggunakan Aplikasi Komputer Statistik SPSS. Jakarta: PT. Gramedia Pustaka Utama 